\title{
Delignification of corncob via combined hydrodynamic cavitation and enzymatic pretreatment: process optimization by response surface methodology
}

\author{
Kiruthika Thangavelu', Ramesh Desikan ${ }^{1 *} \mathbb{D}$, Oxana P. $\operatorname{Taran}^{2}$ and Sivakumar Uthandi ${ }^{3^{*}}$
}

\begin{abstract}
Background: Renewable liquid biofuel production will reduce crude oil import of India. To displace the huge quantity of fossil fuels used for energy production, this research was focused on utilization of unexploited low-cost agricultural residues for biofuel production. Corncobs are a byproduct of corn processing industry, and till now it is not utilized for biofuel production, eventhough it has high lignocellulosic concent. In this study, combined hydrodynamic cavitation and enzymatic (HCE) method was evaluated as a pretreatment method of corncob for biofuel production. The most significant process parameters namely (i) enzyme loading $\left(3-10 \mathrm{U} \mathrm{g}^{-1}\right)$, (ii) biomass loading (2.5-5.0\%), and (iii) duration (5-60 min) were optimized and their effects on combined HCE pretreatment of corncob was studied through response surface methodology for lignin reduction, hemicellulose reduction and cellulose increase.
\end{abstract}

Results: The highest lignin reduction (47.4\%) was obtained in orifice plate $1\left(\mathrm{OP}_{1}\right)$ under the optimized conditions namely biomass loading at $5 \%$, enzyme loading at $6.5 \mathrm{U} \mathrm{g}^{-1}$ of biomass, and reaction duration of $60 \mathrm{~min}$. The above tested independent variables had a significant effect on lignin reduction. The cavitational yield and energy consumption under the above-mentioned optimized conditions for $\mathrm{OP}_{1}$ was $3.56 \times 10^{-5} \mathrm{~g} \mathrm{~J}^{-1}$ and $1.35 \mathrm{MJ} \mathrm{kg}^{-1}$, respectively.

Conclusions: It is evident from the study that HCE is an effective technology and requires less energy $\left(1.35 \mathrm{MJ} \mathrm{kg}^{-1}\right)$ than other biomass pretreatment methods.

Keywords: Corncob, Pretreatment, Delignification, Hydrodynamic cavitation, Laccase enzyme

\section{Background}

Maize (Zea mays L.) is an important cereal grown in India for food and nutritional security, with a total production and productivity of 24 million metric tons and $10.2 \mathrm{t} \mathrm{ha}^{-1}$, respectively. It is estimated that about $180 \mathrm{~kg}$ of cobs are produced per ton of shelled maize, leading to huge amounts of corncob accumulation, which are left

\footnotetext{
*Correspondence: rameshd@tnau.ac.in; usivakumartnau@gmail.com ${ }^{1}$ Department of Bioenergy, Agricultural Engineering College and Research Institute, Tamil Nadu Agricultural University, Coimbatore, Tamil Nadu 641003, India

${ }^{3}$ Biocatalysts Lab, Department of Agricultural Microbiology, Tamil Nadu Agricultural University, Coimbatore, Tamil Nadu 641003, India Full list of author information is available at the end of the article
}

unutilized. Corncobs are a rich source of lignocellulosic material containing primarily cellulose (36\%), hemicelluloses (26\%), and lignin (17\%). Currently, the corncobs are used for production of paper pulp due to its cellulosic contents. However, it can be a better source for biofuel production due to its constituents. It should be noted that corncob is not a food or feed substrate. Production of biofuels and other value-added industrially important fine chemicals from lignocellulosic biomass will not only lower our dependence on fossil fuels and green gas emissions but also would favor the development of sustainable biorefineries. Hence, utilization of corncob is the best resource for deriving useful industrial chemicals and corncob-based biofuel as one of the viable and 
promising approaches for sustainable utilization of natural resources and ensuring energy security.

Conversion of lignocellulosic biomass (LCB) into bioalcohols (bioethanol or biobutanol) involves three stages, viz, biomass pretreatment, hydrolysis, and fermentation and among these biomass pretreatment is an inevitable bioprocesses and consumes up to $40 \%$ of total production cost [1]. Currently, physical or chemical or biological methods or their combinations are employed for biomass pretreatment. The most common biomass deconstruction methods includes physical (grinding/milling [2, 3]), chemical (acid/alkaline [4, 5], ionic liquids [6], subcritical and supercritical water, organosolv [7]), biological (white rot fungi [8] or laccase enzyme [9]), and combinations of these methods (hot water/autohydrolysis [10, 11], steam explosion [11], supercritical $\mathrm{CO}_{2}$ [12] or ammonia fiber explosion [13]). Generally, combined pretreatment methods are preferred due to its better performance/efficiency in delignification compared to individual methods [14]. The biomass pretreatment methods which are used currently are more complex and energy intensive, eventually requires more efforts during scaling up process.

Recently, hydrodynamic cavitation (HC) technology has been successfully employed in diversified fields namely biodiesel production, wastewater treatment, food processing and different bioprocessing operations. Combined HC pretreatment and other chemical catalysts have been used for production of biofuel from different lignocellulosic feedstocks [15-18]. During HC pretreatment, highly reactive radicals $\left(\mathrm{OH}^{-}\right.$and $\left.\mathrm{H}^{-}\right)$are formed in the working fluid due to the cavitation effect, which can cause deconstruction of lignin structures. Though $\mathrm{HC}$ technology has been considered as a viable pretreatment method for processing diverse feedstocks, it is not optimal for targeting specific end products.

The methodology adopted in HC pretreatment studies creates cavitation by continuous circulation of the working fluid (water containing biocatalyst) by a pump through an orifice plate of the reactor. However, the raw biomass has to be kept within or outside of the $\mathrm{HC}$ zone [19]. But in the present investigation, both the biomass and biocatalyst were circulated continuously throughout the reactor to enhance the bioconversion efficiency. The advantages of this approach are less energy requirement and operation at ambient conditions.

Furthermore, biocatalysts such as enzyme use phenoxy radicals for the removal of recalcitrant fractions of lignocellulosic biomass. The best-characterized lignin depolymerizing enzymes are multi copper oxidases namely laccases (EC 1.10.3.2), which utilizes $\mathrm{O}_{2}$ instead of $\mathrm{H}_{2} \mathrm{O}_{2}$ to mediate substrate oxidation and also not prone to cofactor degradation. To the best of our knowledge, combination of $\mathrm{HC}$ and enzyme ( $\mathrm{HCE}$ ) was not attempted so far. In this context, the study highlights the significance of combination of $\mathrm{HC}$ with laccase for pretreatment of corncob biomass, optimization of process variables, and their interaction effects on higher recovery of lignin from corncob.

\section{Results and discussion \\ Optimization of HCE method}

Optimization of HCE pretreatment of delignification was performed using orifice plate $1\left(\mathrm{OP}_{1}\right)$ and orifice plate 2 $\left(\mathrm{OP}_{2}\right)$ at an optimized inlet pressure of 50 and $100 \mathrm{kPa}$, respectively. To determine the optimum values of variables for HCE pretreatment, response surface methodology (RSM) was employed with all the input variables set in the range, with output responses set at maximum levels. For process optimization, three factors were evaluated for three different responses such as maximum lignin reduction (\%), hemicellulose reduction (\%) and cellulose increase (\%) using Box-Behnken design in RSM, which includes biomass loading $(A)$, enzyme loading $(B)$, and time $(C)$. These variables were statistically optimized using $3^{3}$ factorial design.

The optimized conditions for HCE pretreatment with orifice plate 1 ( $\left.\mathrm{HCE}-\mathrm{OP}_{1}\right)$, are biomass loading at $5 \%$, enzyme loading at $6.5 \mathrm{U} \mathrm{g}^{-1}$ of biomass, and a process time of $60 \mathrm{~min}$. The result showed a reduction in lignin (47.4\%) and hemicellulose content (3.2\%) and an increase in cellulose content (25.3\%). Furthermore, it was observed that the biomass loading and duration have resulted in the optimum response with the higher values. However, the enzyme loading resulted in the mid value. The quadratic model of percentage of lignin reduction had a predicted and adjusted $R^{2}$ values of 0.99 and 0.98 , respectively. The predicted $R^{2}$ value was in agreement with the adjusted $R^{2}$ value, since the difference between two values was less than 0.02 , indicating that the model developed will be able to give a reasonably good estimate of the response of the system [20].

An analysis of variance (ANOVA) was conducted to check the adequacy and the significance of the quadratic model. According to ANOVA (Table 1), the $F$ value determined the significance of each term at the designed level of confidence [21]. The $F$ value of percentage of lignin reduction (1166.54) implies that the model is significant. The $p$ value was used to check the significance of each variable and simultaneously identify the effect of each factor on the response $[22,23]$. According to the $p$ values $(p<0.05)$, the linear model terms $(A, B$ and $C)$, the interactive model terms (AC), and the quadratic model terms $\left(C^{2}\right)$ were all significant at $95 \%$ confidence level. Among the interactions studied, biomass loading and duration resulted in probability value ( $p$ value) of 0.0198 , which was highly significant than other interactions. 
Table 1 Analysis of variance (ANOVA) for quadratic model for lignin reduction of corncob pretreated by HCE-OP 1

\begin{tabular}{|c|c|c|c|c|c|c|}
\hline Source & Sum of squares & $\begin{array}{l}\text { Degrees } \\
\text { of freedom }\end{array}$ & Mean square & $F$ value & $p$ value Prob $>F$ & Significance \\
\hline Model & 69.87 & 9 & 7.76 & 1166.54 & $<0.0001$ & Significant \\
\hline$A$ & 0.99 & 1 & 0.99 & 148.91 & $<0.0001$ & \\
\hline$B$ & 0.09 & 1 & 0.09 & 13.6 & 0.0078 & \\
\hline C & 65.97 & 1 & 65.97 & 9912.54 & $<0.0001$ & \\
\hline$A B$ & 0.022 & 1 & 0.022 & 3.27 & 0.1135 & \\
\hline$A C$ & 0.06 & 1 & 0.06 & 9.04 & 0.0198 & \\
\hline$B C$ & $1.06 \mathrm{E}-03$ & 1 & $1.06 \mathrm{E}-03$ & 0.16 & 0.7013 & \\
\hline$A^{2}$ & $7.52 \mathrm{E}-07$ & 1 & $7.52 \mathrm{E}-07$ & $1.13 E-04$ & 0.9918 & \\
\hline$B^{2}$ & $9.66 \mathrm{E}-03$ & 1 & $9.66 \mathrm{E}-03$ & 1.45 & 0.2675 & \\
\hline$C^{2}$ & 2.73 & 1 & 2.73 & 410.21 & $<0.0001$ & \\
\hline Residual & 0.047 & 7 & $6.66 \mathrm{E}-03$ & & & \\
\hline Lack of fit & 0.047 & 3 & 0.016 & & & \\
\hline Pure error & 0 & 4 & 0 & & & \\
\hline Cor total & 69.92 & 16 & & & & \\
\hline Std. dev. & 0.081581 & & & $R$-squared & 0.999334 & \\
\hline Mean & 4.253575 & & & Adj $R$-squared & 0.998477 & \\
\hline C.V. $\%$ & 1.917932 & & & Pred $R$-squared & 0.989339 & \\
\hline Press & 0.745405 & & & Adeq precision & 103.0419 & \\
\hline
\end{tabular}

Furthermore, the variables $A, B$ and $C$ have resulted in significant model terms compared to $\mathrm{AB}$ and $\mathrm{BC}$. In this model, only significant terms are considered. The coefficient of variance $(\mathrm{CV})$ specifies the degree of precision for the treatments and expressed as percentage (\%). The low values of $\mathrm{CV} \%$ clearly indicated a very high degree of precision and a good reliability of the experimental values [20]. Percentage of lignin reduction resulted in a lower $\mathrm{CV}$ value of $1.92 \%$, which showed that the model has high experimental reliability due to closeness of experimental and predicted values [24].

Adequate precision measures the signal to noise ratio and compares the range of the predicted values at the design points to the average prediction error. This ratio was greater than 4 , which is desirable and indicates adequate model discrimination [25]. In the present case, the adequate precision for a percentage of lignin reduction has resulted in a ratio of 103.04, indicating an adequate signal, implying greater predicted response relative associated error.

The response surface plots were generated with one variable kept at its optimum level and other variables varying within the experimental range. The interactions between the model terms were expressed by a threedimensional surface. A check for interactions was necessary to determine the significance of the model equation $[22,23]$. The response surface plots for a percentage of lignin reduction of the $\mathrm{OP}_{1}$ were shown in Fig. 1. An empirical relationship between the response and the variables was expressed by the following quadratic second-order polynomial equation:

$$
\begin{aligned}
\text { Lignin reduction }= & -1.80307+0.505073 \\
& \times A+0.037273 \times B+0.185913 \\
& \times C-0.01686 \times A B-0.00357 \\
& \times A C+0.000169 \times B C+0.000271 \\
& \times A^{2}+0.003909 \times B^{2}-0.00106 \\
& \times C^{2}
\end{aligned}
$$

where $A$ is biomass loading in \%, B is enzyme loading in $\mathrm{U} \mathrm{g}^{-1}$ of biomass, and $C$ is duration in min.

The same experimental designs and conditions were adopted as per $\mathrm{OP}_{1}$ for optimizing variables for $\mathrm{OP}_{2}$. The optimized conditions obtained in HCE pretreatment with plate $2\left(\mathrm{HCE}-\mathrm{OP}_{2}\right)$ were the same as plate 1 , namely biomass loading $(5 \%)$, enzyme loading $\left(6.5 \mathrm{U} \mathrm{g}^{-1}\right)$ and a process time $(60 \mathrm{~min})$. However, in this case, lignin reduction was $35.91 \%$, which was significantly lower than that observed with $\mathrm{OP}_{1}$. This might be due to the cavitation bubbles collapse and inward propagation of the shock waves. The geometric focusing of this shock wave at the centre of the cluster creates the enhancement of the cavity cluster collapse (higher pressure) and noise associated with the cavity cluster collapse [26]. This kind of shock wave formation has been confirmed by Wang and Brennen [27] and Reisman et al. [28]. The collapse of micro bubble cavities generates enormous destructive 

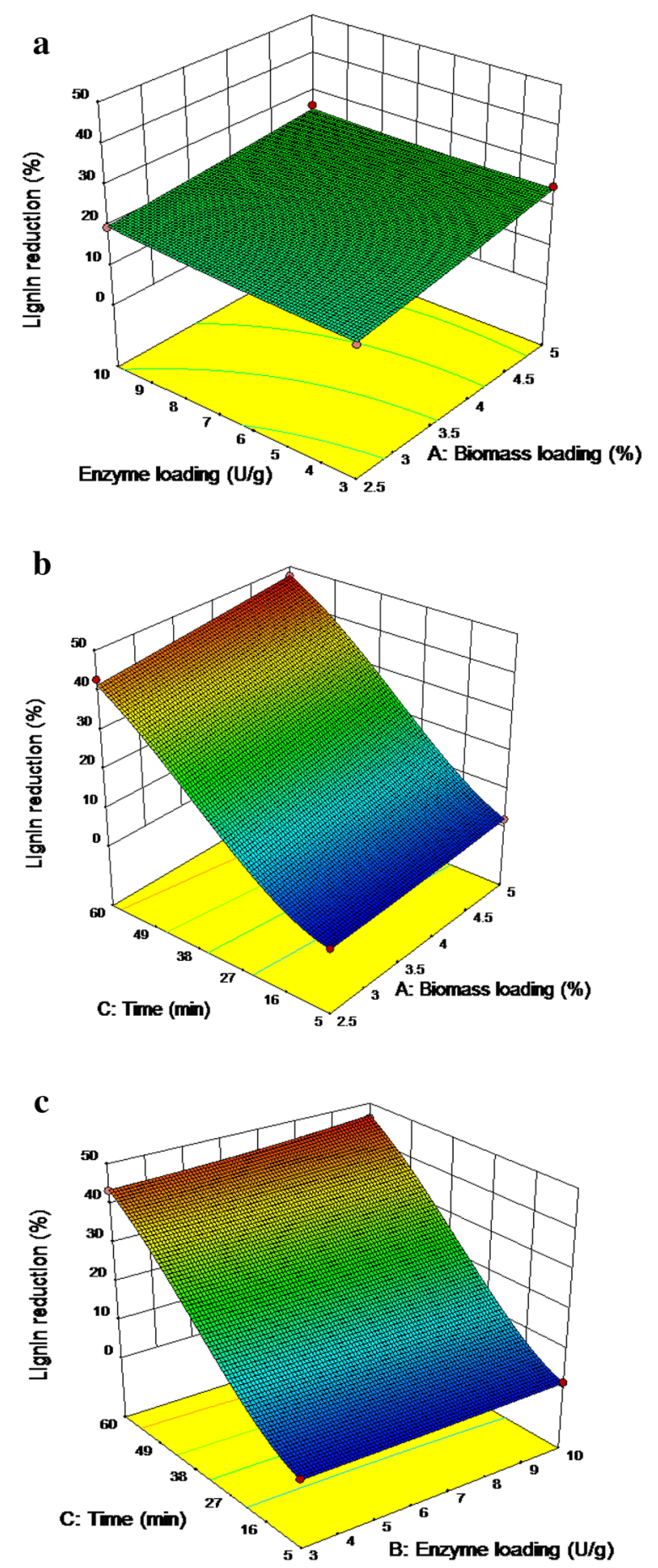

Fig.1 3D plots for response lignin reduction of corncob pretreated by HCE $-\mathrm{OP}_{1}$. a Enzyme loading vs. biomass loading; $\mathbf{b}$ biomass loading vs. time; c enzyme loading vs. time

forces, which not only brings about the disintegration of biomass via high turbulence and micro-jets $[19,29]$, but also due to the dissociation of water molecules, which led to the generation of radicals like $\mathrm{HO}^{-}, \mathrm{HOO}^{-}$, and $\mathrm{O}_{2}^{-}$.
The linear model of lignin reduction (Table 2) showed a predicted and adjusted $R$-squared $\left(R^{2}\right)$ values of 0.94 and 0.96 , respectively, revealing a good agreement between experimental and predicted values besides implying that the mathematical model was very reliable. The $F$ value of 140.32 implies that the model was significant. The compositional analysis of corncob biomass samples after $\mathrm{HCE}$ with $\mathrm{OP}_{1}$ and $\mathrm{OP}_{2}$ are furnished in Additional file 1: Tables S1, S2.

According to the $p$ values $(p<0.05)$, the linear model terms $(A$ and $C)$ are significant at $95 \%$ confidence level. The CV value of 13.43 indicated that the model had reliability of the experimental values. An adequate precision ratio of 130.45 represents an adequate signal. The response surface plots are shown in Fig. 2. The empirical equation fitting the quadratic model is given below:

$$
\begin{aligned}
\text { Lignin reduction }= & 1.818182 \times A+0.318588 \times B \\
& +0.598915 \times C
\end{aligned}
$$

where $A$ is biomass loading in \%, $B$ is enzyme loading in $\mathrm{U} \mathrm{g}^{-1}$ of biomass, and $C$ is duration in min.

The results of the present study are compared with different $\mathrm{HC}$ biomass pretreatment methods which is shown in the Table 3. The present experiment achieved $47 \%$ lignin recovery with a lower optimal temperature of operation. More importantly, the energy consumption for the HCE pretreatment process is very low compared to other reported methods.

\section{Thermal behavior of raw and pretreated biomass}

Thermogravimetric analysis of lignocellulosic biomass was used to study the thermal degradation profiles of hemicellulose $\left(250-300{ }^{\circ} \mathrm{C}\right)$, cellulose $\left(300-350{ }^{\circ} \mathrm{C}\right)$, and lignin $\left(300-500{ }^{\circ} \mathrm{C}\right)[31,32]$. The appearance of the derivative thermogravimetry (DTG) peak at $200-400{ }^{\circ} \mathrm{C}$ was pertaining to hemicellulose and cellulose component [31]. This information enables comparison of the changes in composition of biomass due to pretreatment method [33, 34]. Furthermore, it was clear that the two peaks observed between 200 and $400{ }^{\circ} \mathrm{C}$ in the DTG curves was associated with the degradation of hemicellulose and cellulose of the sample. Perhaps the ranges of temperature for decomposition of lignin would have overlapped partially with that of hemicelluloses and cellulose. It is obvious that the temperature associated with two DTG peaks of pretreated corncob samples was higher than raw sample and this could be due to pretreatment effect (Fig. 3 and Table 4).

Apart from temperature change, the peaks also differed in position and height indicating changes in proximate composition namely reduction in lignin and hemicellulose and increase in cellulose content, that might be happened during pretreatment process. 
Table 2 Analysis of variance (ANOVA) for linear model for lignin reduction of corncob pretreated by HCE -OP

\begin{tabular}{|c|c|c|c|c|c|c|}
\hline Source & Sum of squares & $\begin{array}{l}\text { Degrees } \\
\text { of freedom }\end{array}$ & Mean square & $F$ value & $p$ value Prob $>F$ & Significance \\
\hline Model & 2221.40 & 3 & 740.47 & 140.32 & $<0.0001$ & Significant \\
\hline$A$ & 41.32 & 1 & 41.32 & 7.83 & 0.0151 & \\
\hline B & 9.95 & 1 & 9.95 & 1.88 & 0.1930 & \\
\hline$C$ & 2170.13 & 1 & 2170.13 & 411.25 & $<0.0001$ & \\
\hline Residual & 68.60 & 13 & 5.28 & & & \\
\hline Lack of fit & 68.60 & 9 & 7.62 & & & \\
\hline Pure error & 0.00 & 4 & 0 & & & \\
\hline Cor total & 2290.00 & 16 & & & & \\
\hline Std. dev. & 2.30 & & $R$-squared & 0.9700 & & \\
\hline Mean & 17.11 & & Adj $R$-squared & 0.9631 & & \\
\hline C.V. $\%$ & 13.43 & & Pred $R$-squared & 0.9430 & & \\
\hline Press & 130.45 & & Adeq precision & 33.6410 & & \\
\hline
\end{tabular}

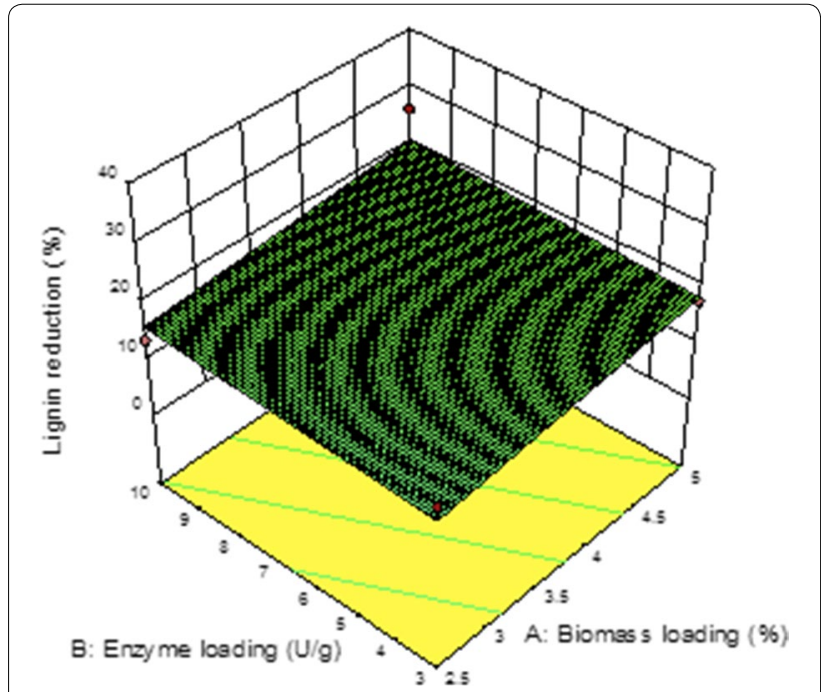

Fig.2 3D plots for response lignin reduction of corncob pretreated by $\mathrm{HCE}-\mathrm{OP}_{2}$ —enzyme loading vs. biomass loading

\section{FT-IR analysis}

Pretreated sample was analyzed by Fourier-transform infrared (FT-IR), and the different wave numbers, functional groups and their corresponding polymer were presented in Table 5. It is evident that raw corncob showed clear peaks for cellulose, hemicellulose and lignin at the corresponding wave numbers.

The performance of combined HCE pretreatment indicated that there were no major changes in hemicellulose. However, both the orifice plates behaved differently with regard to lignin removal.

A reduction in peak intensity was observed under $\mathrm{OP}_{1}$ than $\mathrm{OP}_{2}$ compared to the raw biomass, at wave numbers 1320, 1424, 1445, and $1509 \mathrm{~cm}^{-1}$ (Fig. 4). This signifies that lignin removal was higher in $\mathrm{OP}_{1}$, and $\mathrm{OP}_{2}$ was less efficient. Probably this difference between the plates could be attributed to the less number of radicals formed in the cavitational zone by the $\mathrm{OP}_{2}$. Moreover, other functional groups also showed similar changes in both $\mathrm{OP}_{1}$ and $\mathrm{OP}_{2}$.

\section{Scanning electron microscopy (SEM)}

The SEM images of raw sample shows a smooth and undisturbed surface (Fig. 5a). By contrast, after the HCE pretreatment, pores appeared on the surface, and it could be due to removal of lignin. According to Grimaldi et al. [35], the biomass pretreatment removes lignin through destruction of cell wall in two stages namely, loss of cohesion between neighboring cell walls, and degradation inside the cell wall by peeling off and forming holes. The breakdown of structure and pinholes in the surface area of treated sample by cavitation could have enhanced the accessibility for hydrolytic enzymes for increasing the saccharification process [36]. HCE-generated potholes in biomass might have occurred due to collapse of the cavities at the surface of the biomass particles, which could lead to a shear of bimolecular structures, while subsequent laccase treatment led to increase in pothole size $(1-6 \mu \mathrm{m})$. This indicates effective removal of lignin and deconstruction of biomass in $\mathrm{OP}_{1}$ than $\mathrm{OP}_{2}(\max .2 \mu \mathrm{m})$ (Fig. 5b, c), which could be attributed to the higher intensity of cavities collapse and turbulence generated in $\mathrm{OP}_{1}$ that resulted in a loosening of the biomass for the effective action of laccase than in plate 2 .

\section{X-ray diffraction (XRD)}

Raw and pretreated samples were estimated for cellulose crystallinity changes. The value of crystallinity index of pretreated samples $(56.0 \%)$ for both the orifice plates 
Table 3 Comparison of different HC biomass pretreatment methods

\begin{tabular}{|c|c|c|c|c|c|}
\hline S. no. & Parameters & Hilares et al. [30] & Hilares et al. [18] & Kim et al. [19] & Present study \\
\hline 1 & Biomass & Sugarcane bagasse & Sugarcane bagasse & Reed & Corncob \\
\hline 2 & Feedstock size & $4.7 \mathrm{~mm}$ & $1.18-1.70 \mathrm{~mm}$ & $10 \mathrm{~mm}$ & $\leq 212 \mu \mathrm{m}$ \\
\hline 3 & Type of plate & Orifice & Orifice & Orifice & Orifice \\
\hline 4 & Number of holes & $16(\emptyset=1 \mathrm{~mm})$ & $27(\emptyset=1 \mathrm{~mm})$ & $27(\emptyset=1 \mathrm{~mm})$ & $9(\emptyset=2 \mathrm{~mm})$ \\
\hline 5 & Operating temperature, ${ }^{\circ} \mathrm{C}$ & 70 & 64 & 77 & 30 \\
\hline 6 & Inlet pressure, $\mathrm{kPa}$ & 300 & 300 & 500 & 50 \\
\hline 7 & Reaction time, min. & 30 & 44.48 & 41.1 & 60 \\
\hline 8 & Biomass loading, $\%$ & - & 4.27 & 11.8 & 5.0 \\
\hline 9 & Catalyst & $0.3 \mathrm{M} \mathrm{NaOH}$ & $0.48 \mathrm{M} \mathrm{NaOH}$ & $3.0 \% \mathrm{NaOH}$ & $\begin{array}{l}\text { Laccase enzyme: } 6.5 \mathrm{U} \mathrm{g}^{-1} \text { of } \\
\text { biomass }\end{array}$ \\
\hline 10 & Liquid volume, ml & 2500 & 2500 & 150 & 4000 \\
\hline 11 & Biomass placement & $\begin{array}{l}\text { Cavitation zone (Cylin- } \\
\text { drical wire cloth: } 18 \\
\text { mesh) }\end{array}$ & $\begin{array}{l}\text { Cavitation zone (Cylin- } \\
\text { drical wire cloth: } 18 \\
\text { mesh) }\end{array}$ & $\begin{array}{l}\text { Cavitation zone } \\
\text { (woven wire cloth: } \\
40 \text { mesh) }\end{array}$ & $\begin{array}{l}\text { Mixed with acetate buffer and } \\
\text { circulated in a closed loop }\end{array}$ \\
\hline 12 & Lignin removal, \% & 51.52 & 60.4 & $35-42$ & 47.44 \\
\hline 13 & Cavitational yield, $\mathrm{g} \mathrm{J}^{-1}$ & - & - & - & $3.56 \times 10^{-5}$ \\
\hline 15 & Energy consumption, $\mathrm{MJ} \mathrm{kg}^{-1}$ & - & - & 3.65 & 1.35 \\
\hline
\end{tabular}

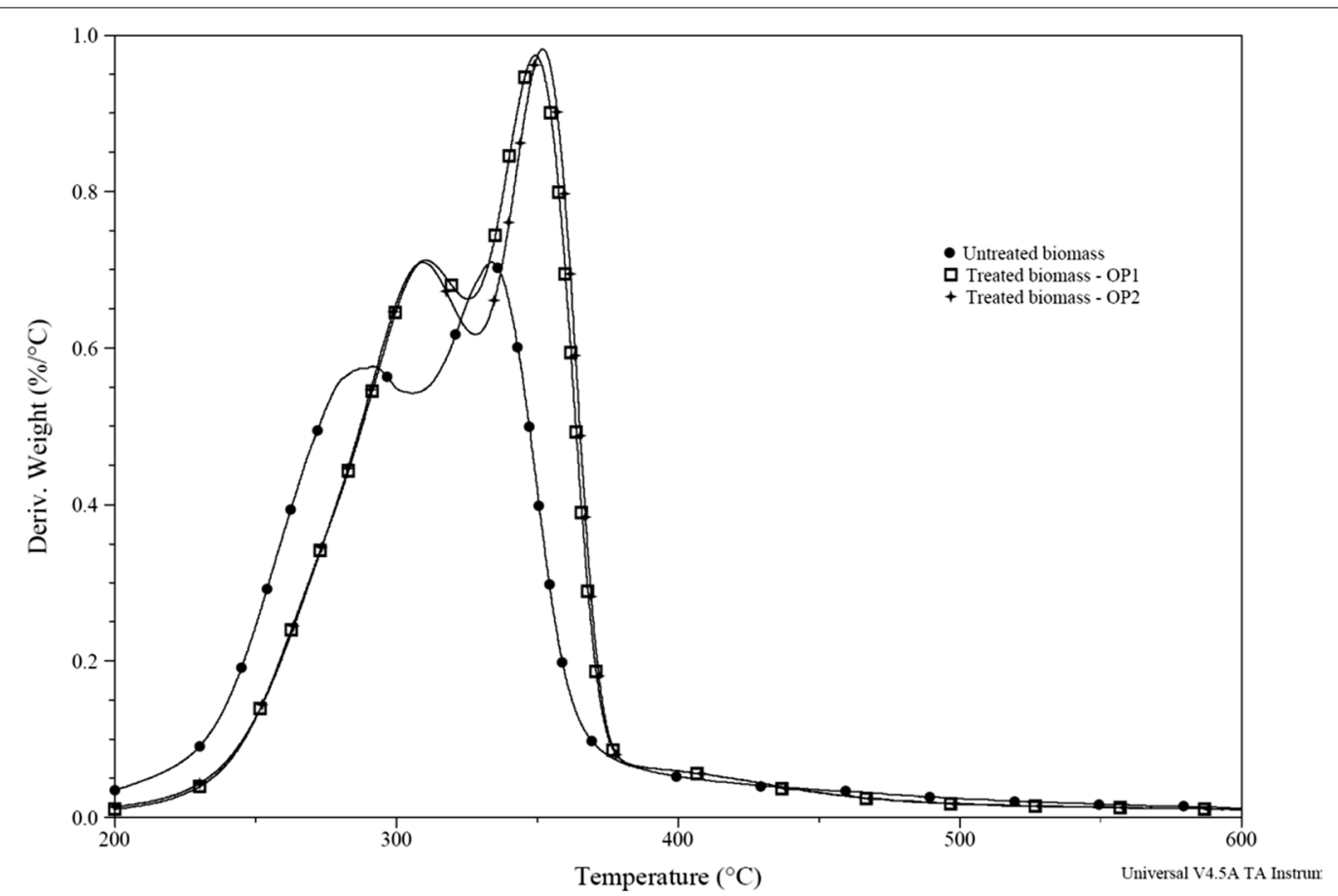

Fig. 3 Combined DTG curves for raw and HCE pretreated corncob biomass samples

were higher than the raw sample (52.4\%), indicating that HCE pretreatment was more efficient in the removal of amorphous fraction as compared to crystalline fractions. No significant change in the crystallinity of cellulose between treatments and type of plates was observed. This observation testifies that laccase removed only lignin and not changed the cellulose crystallinity. Instead, the HCE pretreatment improved the accessibility of cellulose without modifying the cellulose structure. 
Table 4 Details of temperature at peak 1 and peak 2 for corncob biomass obtained from DTG curves

\begin{tabular}{lllr}
\hline Type of biomass & Catalyst used & \multicolumn{2}{l}{ Temperature, ${ }^{\circ} \mathrm{C}$ (maximum loss rate, \%/ $\left.{ }^{\circ} \mathrm{C}\right)$} \\
\cline { 3 - 4 } & & Peak 1 & Peak 2 \\
\hline Raw corncob & - & $290.7\left(0.5753 \% /{ }^{\circ} \mathrm{C}\right)$ & $333.7\left(0.7088 \% /{ }^{\circ} \mathrm{C}\right)$ \\
Pretreated biomass (HCE-OP $)$ & $6.5 \mathrm{U}$ of enzyme g ${ }^{-1}$ of dry biomass & $310.9\left(0.7122 \% /{ }^{\circ} \mathrm{C}\right)$ & $349.0\left(0.9737 \% /{ }^{\circ} \mathrm{C}\right)$ \\
Pretreated biomass $\left(\mathrm{HCE}-\mathrm{OP}_{2}\right)$ & $6.5 \mathrm{U}$ of enzyme g ${ }^{-1}$ of dry biomass & $310.4\left(0.7092 \% /{ }^{\circ} \mathrm{C}\right)$ & $352.0\left(0.9820 \% /{ }^{\circ} \mathrm{C}\right)$ \\
\hline
\end{tabular}

Table 5 Assignment of functional groups and their corresponding polymers in pretreated corncob

\begin{tabular}{lll}
\hline Wavenumber & Functional groups & Corresponding polymer \\
\hline 3340 & $\mathrm{O}-\mathrm{H}$ stretch & Lignin \\
2833 & $\mathrm{C}-\mathrm{H}$ stretch & Lignin \\
1634 & Aromatic ring vibration & Lignin \\
1509 & $\mathrm{C}=\mathrm{C}$ & Lignin \\
1422 & $\mathrm{CH}_{2}$ & Lignin \\
1321 & $\mathrm{C}-\mathrm{O}-\mathrm{CH}$ vibration & Lignin \\
1247 & $\mathrm{C}-\mathrm{O}$ stretching & Syringyl units \\
1157 & $\mathrm{C}-\mathrm{O}-\mathrm{C}$ asymmetrical stretching & Hemicellulose (xylose) \\
1031 & $\mathrm{C}-\mathrm{O}, \mathrm{C}=\mathrm{C}, \mathrm{C}-\mathrm{C}-\mathrm{O}$ stretching & Cellulose, hemicellulose and lignin
\end{tabular}

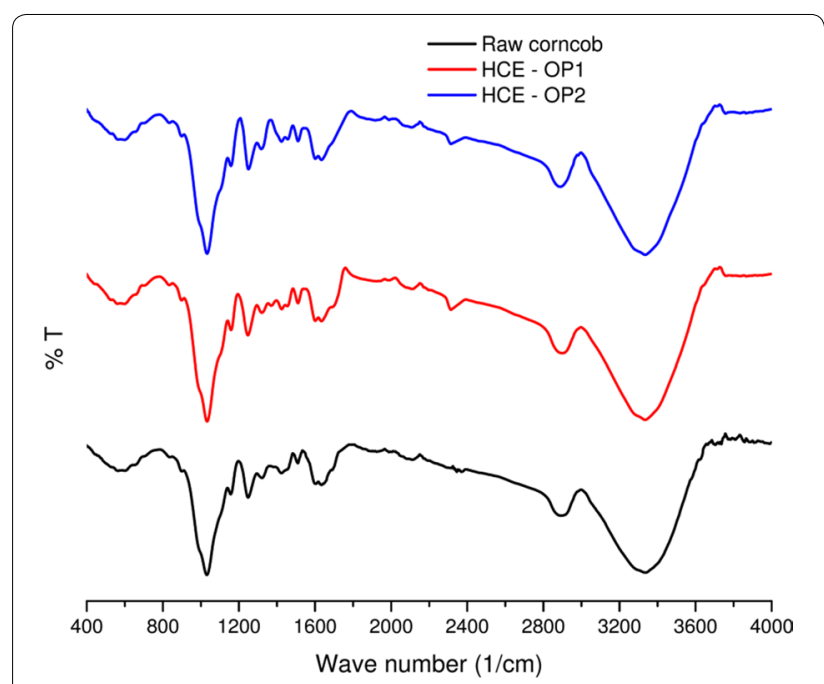

Fig. 4 FTIR spectrum for raw and HCE pretreated corncob samples

\section{Cavitational yield and energy consumption}

The optimized conditions for biomass treatment in $\mathrm{HCE}$ pretreatment with $\mathrm{OP}_{1}$ and $\mathrm{OP}_{2}$ were biomass loading at $5 \%$, enzyme loading at $6.5 \mathrm{U} \mathrm{g}^{-1}$ of biomass, and a process time of $60 \mathrm{~min}$. Energy consumption in the HCE pretreatment process for $\mathrm{OP}_{1}\left(1.35 \mathrm{MJ} \mathrm{kg}{ }^{-1}\right)$ was lower than $\mathrm{OP}_{2}\left(3.24 \mathrm{MJ} \mathrm{kg}^{-1}\right)$ with cavitational yields of $3.56 \times 10^{-5}$ and $2.70 \times 10^{-5} \mathrm{~g} \mathrm{~J}^{-1}$, respectively, under optimized conditions for $\mathrm{OP}_{1}$ and $\mathrm{OP}_{2}$ for the enzyme pretreatment.

\section{Materials}

\section{Biomass preparation}

The corncob biomass was procured from the farmer fields, Coimbatore, Tamil Nadu, India and dried at ambient temperature $\left(30{ }^{\circ} \mathrm{C}\right)$ for $12 \mathrm{~h}$ to reduce the moisture content from 20 to $14 \%$, then the size was reduced in a sequence through shredder (Chudekar Agro Engg Pvt Ltd., Model: $53 \mathrm{H}$, India), pin mill (Premium Pulman Pvt Ltd., Model: PPM-12, India) and grinder (Aashapura Enterprises, Model: Stylo 750, India) to $\leq 212 \mu \mathrm{m}$, which was sieved via ASTM sieve size No. 70 .

\section{Enzyme selection}

Generally, two families of ligninolytic enzymes are widely considered for enzymatic delignification, which includes phenol oxidase (laccase) and peroxidases (lignin peroxidase, or LiP and manganese peroxidase, or MnP) [37]. Laccase belongs to the copper oxidase enzyme family, similar to other phenol-oxidizing enzymes and it preferably polymerizes lignin by coupling of the phenoxy radicals produced from oxidation of lignin phenolic groups. Laccase enzyme was selected and used as catalyst for this HCE pretreatment [38].

The enzyme laccase used in the study was from microbial source (Trametes versicolor). The laccase was purchased from Sigma-Aldrich, Bangalore, India and used as such. The laccase activity was determined with the reaction mixture contained appropriately diluted enzyme mixed with $1 \mathrm{mM}$ ABTS in sodium phosphate buffer 


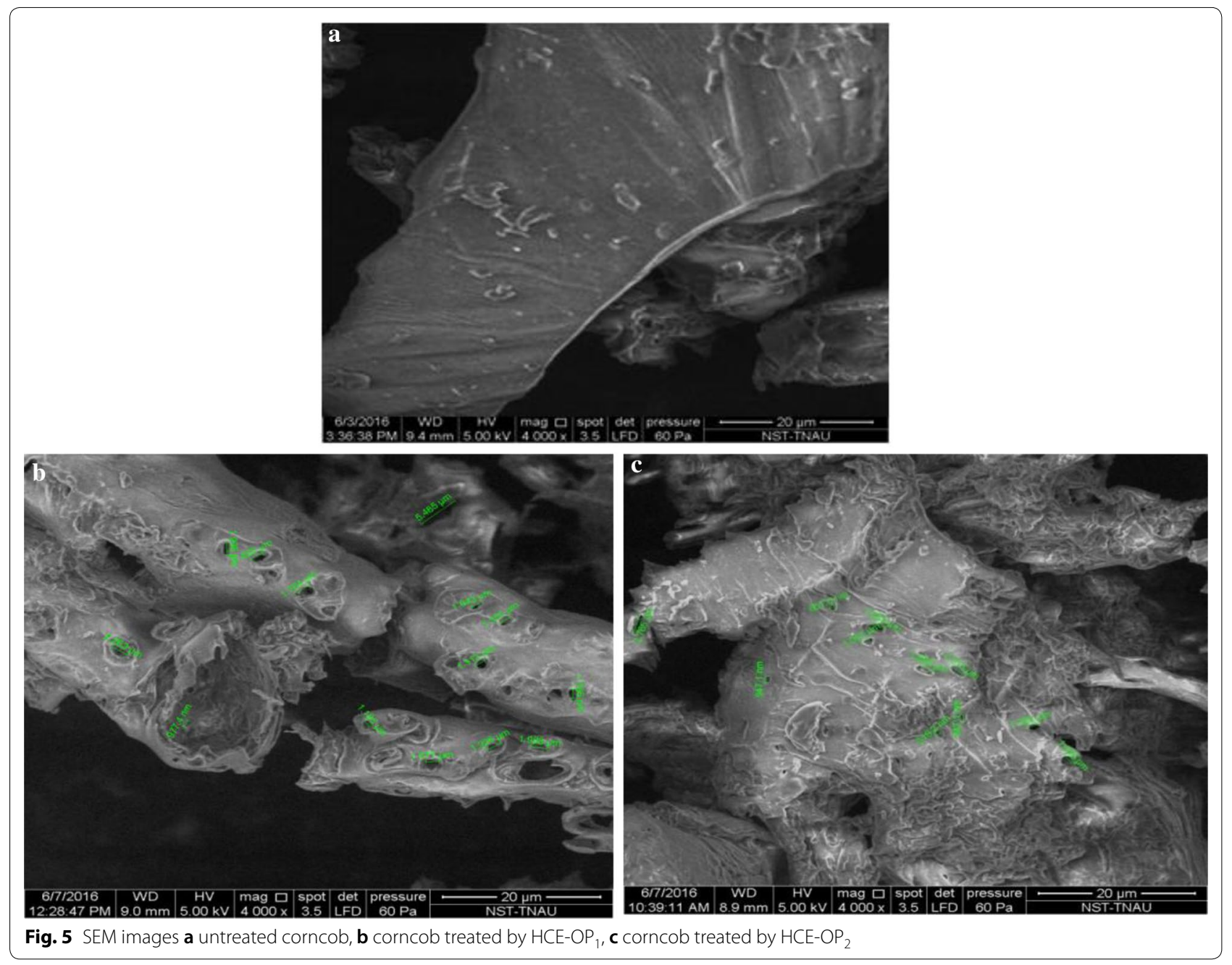

(50 mM, pH 4.5) at $30{ }^{\circ} \mathrm{C}$ for 5 min. using $1 \mathrm{mM}$ ABTS by monitoring changes in absorbance at $420 \mathrm{~nm}$ (€ $\left.\max =3.6 \times 104 \mathrm{M}^{-1} \mathrm{~cm}^{-1}\right)$ spectrophotometrically in a Spectramax 360 (Molecular devices, USA). One unit of enzyme activity refers to the amount of enzyme required to oxidize $1 \mu \mathrm{M} \mathrm{min}^{-1}$ of the ABTS substrate under standard assay conditions.

\section{System description and operating conditions}

The main hurdles associated with commercialization of higher biomass loading pretreatment reactors are complexity of design, reactor geometry and upscale, poor mixing characteristics of reactants, and it is an energy-intensive process. For these reasons, low biomass loading rate $(<20 \%)$ is largely preferred in most of the biomass pretreatments [39]. The main criteria to be considered for reactor design is rheological properties of different slurries collected from different unit operations in the fermentation process [40]. Mostly, water with catalyst is used as the working fluid in the recent $\mathrm{HC}$ biomass pretreatment studies; whereas, in the present study corncob biomass slurry (buffer + biocatalyst + powdered biomass) was used as the working liquid. The process design of this pretreatment is to supply the biomass slurry via holes in the orifice plate to cavitation zone. The rheological study involving different corncob biomass slurries $(2.50,3.75,5.00,6.75$, $7.50,8.75$ and $10.00 \%)$ showed increased viscosity and yield stress, along with increased biomass solid loading and these slurries exhibit pseudo-plastic or shearthinning behavior [41]. It is also observed that high biomass loading rate $(>6.75 \%)$ of corncob slurry have blocked the holes in orifice plate. Based on this result, low biomass loading rates $(2.50,3.75$ and 5.00\%) were selected for HCE pretreatment. Hydrodynamic cavitation reactor (HCR) consists of circulation tank $(6 \mathrm{~L}$ capacity), orifice plate, flanges for orifice plate, centrifugal pump, electrical motor, gate valves for priming and bypass, pressure gauges, and pipe accessories (Fig. 6a). Two pressure gauges $\left(P_{1}\right.$ and $\left.P_{2}\right)$ were fixed on both the 


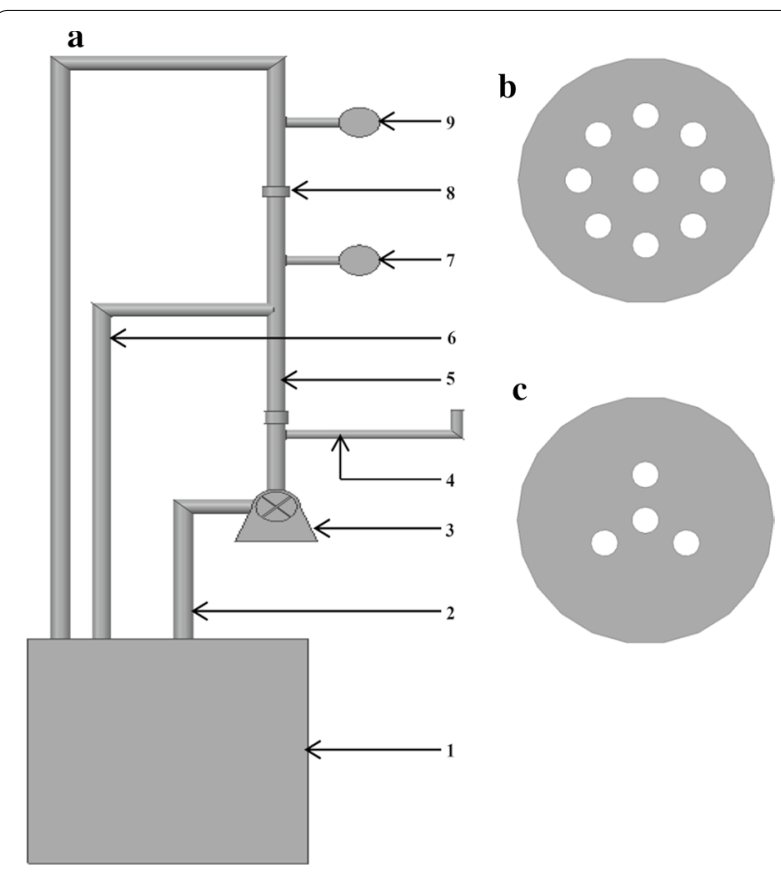

1. Circulation tank

2. Suction pipe line

3. Centrifugal pump coupled with electrical motor

4. Pipe line with gate valve for priming

5. Main line

6. Bypass line

7. Pressure gauge at upstream side

8. Orifice plate with flange arrangement

9. Pressure gauge at downstream side

Fig. 6 a Hydrodynamic cavitation reactor, b orifice plate 1, c orifice plate 2

downstream and upstream sides of the orifice plate to measure the pressure drop. For same area opening in the orifice plate, higher diameter of the hole is recommended for intensive cavitation applications and vice versa. In this reactor, total hole area openings made in the plate were kept as constant $\left(28.26 \mathrm{~mm}^{2}\right)$ and for constant area openings, two configurations of orifice plates were used, viz., orifice plate $1\left(\mathrm{OP}_{1}: 9\right.$ holes and $2 \mathrm{~mm} \varnothing)$ and orifice plate $2\left(\mathrm{OP}_{2}: 4\right.$ holes and $\left.3 \mathrm{~mm} \varnothing\right)$ (Fig. 6c). The suction pipe of the pump was connected at the base of the circulation tank. The main pipeline was divided into three sub-pipelines to serve for three purposes namely priming, bypass line, sub mainline to accommodate flanges and orifice plate, and it was connected to the delivery pipe of the centrifugal pump. To make a closed loop circulation, the working fluid was supplied from the circulation tank to the orifice plate with the help of a centrifugal pump and then sent back to circulation tank. The purpose of the bypass valve was to regulate the flow rate/pressure of the working fluid (biomass slurry) by passing through the orifice plate of the reactor.

For HCE biomass pretreatment, the biomass slurry was prepared by mixing appropriate quantities of biomass powder and a biocatalyst (laccase enzyme) in an acetate buffer $\mathrm{pH}$ 4.5. For example, $200 \mathrm{~g}$ of biomass and $6.5 \mathrm{U} \mathrm{g}^{-1}$ of enzyme were added to $4000 \mathrm{~mL}$ of acetate buffer to make biomass slurry for $5 \%$ biomass loading and $6.5 \mathrm{U} \mathrm{g}^{-1}$ of enzyme. The prepared slurry was added to circulation tank and made to circulate via selected orifice plate continuously, which enabled the biomass to get exposed to cavitation action. Cavitation involves production and aggressive collapse of micro bubbles to generate more hotspots, having higher temperature and pressure. This is sufficient to make the chemical and physical transformations in the lignocellulosic biomass. During the process, decomposition of water molecule causes free radical formation, such as hydroxyl radicals leading to turbulence action of working fluid in the cavitation zone, which eventually helps in rupturing the lignin barrier. Laccase enzyme can oxidize a variety of phenolic subunits of lignin and other aromatic compounds via radical-catalyzed mechanism to yield oxygen-centred free radical and quinine for subsequent reduction in the polymerization reaction [42-44]. Hence, HCE-based biomass treatment helps in the generation of highly reactive free radicals in HCR, which can improve the mass transport process rates and enhance the lignin degradation. Based on these results, three biomass loadings (2.50, 3.75 and 5.00\%) were selected for HCE pretreatment.

\section{Compositional analysis}

After each run, the biomass slurry was collected from the circulation tank, and filtered via filter cloth to separate the pretreated biomass from supernatant. The supernatant was stored at $4{ }^{\circ} \mathrm{C}$ for further analysis. The pretreated biomass was washed twice with distilled water to obtain a neutral $\mathrm{pH}$ of 7.0 and the biomass samples were dried in a hot air oven at $45^{\circ} \mathrm{C}$ for compositional analysis. National Renewable Energy Laboratory procedure was adopted for analyzing biomass composition of raw and pretreated samples [45]. The percentage of lignin reduction by the pretreatment process was calculated using the following equation. 


$$
\text { Percentage of lignin reduction }=\frac{\text { lignin in raw biomass-lignin in pretreated biomass }}{\text { lignin in the raw biomass }} \times 100
$$

\section{Experimental design}

Response surface methodology (RSM) is a statistical and mathematical technique widely used for optimization of process parameters and their interactions on output response(s). The added advantages of optimization via RSM approach are (i) only a minimum number of trials are sufficient to find optimum, (ii) to find a correlation between independent inputs and output responses and (iii) reduction in time, materials and cost because of the less number of trials are needed [46]. The optimization of biomass pretreatment process involves studying the influence of operational parameters and their interactions on lignin removal from raw biomass. For enzymatic biomass pretreatment, process parameters such as biomass loading, enzyme loading and reaction time are crucial factors in deconstruction of the lignin structure as well as lead to release of reducing sugars due to solubilization of biomass.

Response surface methodology (RSM) was employed to determine the optimal conditions for HCE pretreatment to attain the maximum percentage of lignin reduction in the corncob biomass samples. The response was assumed to be influenced by three independent variables, catalyst concentration $(A)$, biomass to liquid ratio $(B)$ and reaction time $(C)$. The range of three selected independent variables used for pretreatment process are: biomass loading of $2.5-5.0 \%$, enzyme loading of 3-10 $\mathrm{U} \mathrm{g}^{-1}$ of dried biomass, and reaction time of 5-60 min. Based on the results of the preliminary trials, the above range of levels of the three independent variables were fixed. A total of 17 experimental trials of the three variables were designed by Box-Behnken design via Design-Expert software 10.0 (Stat-Ease, Inc., USA) [47].

\section{Structural composition of biomass FT-IR analysis}

The FT-IR spectra of the tested biomass samples were obtained using an FT-IR (FT-IR 6800 JASCO, Japan). Absorbance spectra were recorded between 4000 and $400 \mathrm{~cm}^{-1}$ wave numbers with a spectral resolution of $4 \mathrm{~cm}^{-1}$ and 64 scans per sample.

\section{SEM analysis}

The morphology of raw and pretreated corncob biomass was analyzed by scanning electron microscope (SEM; Quanta 250, FEI, Hillsboro, OR, USA) using an
Everhart-Thornley Detector (ETD) detector. The SEM was operated in a vacuum, $10 \mathrm{kV}$, with a spot size of 4 and a pressure of $20 \mathrm{~Pa}$. The sample images were taken at $\times 4000$ magnification.

\section{XRD analysis}

The cellulose crystallinity of the biomass samples was measured using an Ultima IV diffractometer (Rigaku, Japan). Copper $\mathrm{K} \alpha$ radiation, $30.0 \mathrm{kV}$ of voltage, $15 \mathrm{~mA}$ of current, and a rate of $2.0^{\circ} \mathrm{min}^{-1}$ for a $2 \theta$ continuous scan from $4.0^{\circ}$ to $70.0^{\circ}$ were applied. The crystallinity index was obtained from the ratio of the maximum peak intensity $002\left(I_{002}, 2 \theta=22.0\right)$ and minimal depression $\left(I_{\mathrm{am}}\right.$ $2 \theta=16.5)$ between peaks 001 and $002[48,49]$.

$$
\text { Crystallinity index }=\frac{I_{002}-I_{\mathrm{am}}}{I_{002}} \times 100
$$

where $I_{002}$ is the diffraction intensity at $2 \theta=22.5^{\circ}$, which represents both the crystalline and amorphous regions, and $I_{\mathrm{am}}$ is the diffraction intensity at $2 \theta=18.5^{\circ}$, which represents the amorphous regions.

\section{Thermogravimetric analysis (TGA)}

The sample size of the corncob used in the experiment was $10 \pm 2 \mathrm{mg}$ in a thermogravimetric analyzer (TA instruments, Model: TGA Q50, USA). The test sample was heated at a heating rate of $10{ }^{\circ} \mathrm{C} \mathrm{min}{ }^{-1}$ for the temperature range from 50 to $800{ }^{\circ} \mathrm{C}$ and nitrogen gas was

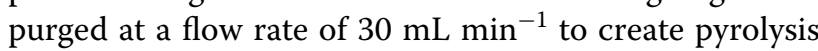
conditions. TGA curve was plotted using TA software (TA Universal Analysis 2000) for both raw and pretreated samples and the results were compared.

\section{Effect of cavitation on temperature of working liquid and residual enzyme activity}

During the experimental trials, the temperature of the working liquid was measured at an interval of $5 \mathrm{~min}$ by digital thermometer (Multi-thermometer, India). Similarly, the residual enzyme activity during the reaction period was also determined [50].

\section{Working liquid temperature}

The acetate buffer was used as working liquid in the HCE biomass pretreatment and there was a rise in the temperature of the working liquid from 30 to $50{ }^{\circ} \mathrm{C}$ in $60 \mathrm{~min}$, 
which could be attributed to heat energy dissipation by sudden collapses of bubbles and cavities. Since laccase enzyme was used, the temperature of working liquid was maintained at $30^{\circ} \mathrm{C}$ by circulating cold water to circulation tank during the experiment.

\section{Residual enzyme activity}

Enzyme's protein conformation changes in temperature, $\mathrm{pH}$, ion concentration, and mechanical stress, and microenvironment of a solution. In this study it was observed that, the laccase enzyme was still active $\left(\mathrm{OP}_{1}: 23.5 \%\right.$, $\left.\mathrm{OP}_{2}: 32.05 \%\right)$ after HCE treatment, this implies that the residual enzyme can be reused for another batch of pretreatment. For $\mathrm{OP}_{1}$, operated with inlet pressure of $50 \mathrm{kPa}$, the residual enzyme activities at 5, 10, 20 and 30 min were $34.2,28.6,23.5$, and $23.5 \%$, respectively. The residual enzyme activity was initially reduced and stabilized after $30 \mathrm{~min}$. While $\mathrm{OP}_{2}$ operating with inlet pressure of $100 \mathrm{kPa}$ showed that the residual enzyme activity was gradually reduced over time (34.2, 33.1, 32.1 and $32.05 \%$ in 5, 10, 20 and 30 min, respectively). Typically, the residual enzyme activity obtained for $\mathrm{OP}_{1}$ was less than that of $\mathrm{OP}_{2}$, possibly due to variation in higher inlet pressure, coupled with hole numbers and diameter. The frequency of turbulence decreases with an increase in the diameter of the orifice hole [51]. Laccase, being a green catalyst, is widely used for delignification. Although it contributes for the cost factor, in this study, we have shown that laccase after HCE treatment did not lose its activity much. This indicates that the enzyme can be reused for further pretreatment.

\section{Cavitational yield}

The cavitational yield is the result of several design parameters optimized for cavitating reactor $[52,53]$. This yield can be enhanced by changing flow conditions and reactor geometry. The orifice plates with higher holes results higher cavitational yield due to increased cavitational effects. Cavitational yield can be defined as number of molecules degraded per unit energy dissipated.

$$
\text { Cavitational yield }=8.834 \times 10^{-11}\left(P_{\text {collapse }}\right)^{1.1633}
$$

Collapse pressure can be predicted by

$$
P_{\text {collapse }}=7527(F)^{-2.55} \times\left(P_{I}\right)^{2.46}\left(R_{0}\right)^{-0.80}\left(d_{o}\right)^{2.37}
$$

where $R_{0}$ is the initial cavity size, $\mathrm{mm} ; P_{\mathrm{I}}$ is the inlet pressure, atm; Do is the diameter of the hole in the orifice plate, $\mathrm{mm} ; F$ is the percentage free area of holes in the total cross-sectional area of the pipe

\section{The energy required per $\mathrm{kg}$ of biomass in an HCE pretreatment process}

The energy consumed for treating one $\mathrm{kg}$ of biomass by the HCE pretreatment process was calculated by the following equation.

$$
\begin{aligned}
& \text { Energy consumption, } \mathrm{MJ} / \mathrm{kg} \\
& =\frac{\text { Inlet pressure }\left(\frac{\mathrm{N}}{\mathrm{m}^{2}}\right) \times \text { flowrate }\left(\mathrm{m}^{3}\right) \times \text { reaction time }(s)}{\text { Weight of biomass used }(\mathrm{kg})}
\end{aligned}
$$

\section{Conclusion}

Based on the results it is clear that HCE pretreatment process have decreased the lignin content and increased the cellulose recovery from corncob. The optimum conditions were $5 \%$ of biomass loading, $6.5 \mathrm{U} \mathrm{g}^{-1}$ of enzyme loading and the process time of $60 \mathrm{~min}$ to get a maximum reduction in lignin content. The percent reduction of lignin by $\mathrm{OP}_{1}$ and $\mathrm{OP}_{2}$ were 47.44 and $35.91 \%$, respectively. This study provides evidence that $\mathrm{HCE}$ pretreatment is more efficient in decreasing the lignin content. However, for scaling up, $5 \%$ of biomass loading seems to be low and may be increased to achieve an economic output. We hypothesize that it can be accomplished by altering the orifice plate configuration and operating pressure. The conformity studies (TGA, FT-IR, SEM and XRD) have confirmed the deconstruction of biomass, removal of lignin and increase in cellulose accessability by HCE pretreatment. Overall, HCE pretreatment technology is advantageous than other pretreatment method because it requires lesser energy and easy to scale up, and can be used in conjunction with generation of biofuel and other LC-derived bioproducts from biomass as a pretreatment process.

\section{Additional file}

Additional file 1: Table S1. Results of compositional analysis of pretreated biomass and lignin reduction (\%) for HCE with $\mathrm{OP}_{1}$. Table S2. Results of compositional analysis of pretreated biomass and lignin reduction (\%) for HCE with $\mathrm{OP}_{2}$.

\footnotetext{
Abbreviations

ANOVA: analysis of variance; Crl: crystallinity index; CV: coefficient of variance; DTG: derivative thermogravimetry; FT-IR: Fourier-transform infrared; HC: hydrodynamic cavitation; HCE: hydrodynamic cavitation and enzymatic pretreatment; HCR: hydrodynamic cavitation reactor; LC: lignocellulosics; LCB: lignocellulosic biomass; NREL: National Renewable Energy Laboratory; $\mathrm{OP}_{1}$ : orifice plate 1; $\mathrm{OP}_{2}$ : orifice plate $2 ; \mathrm{RSM}$ : response surface methodology; SEM: scanning electron microscopy; TGA: thermogravimetric analysis; XRD: X-ray diffraction.
}

\section{Authors' contributions}

SU has received research grants from DBT, Government of India and conceptualized the idea. KT executed most of the experiments, RD supervised the works. OTP is Co-PI of the project. All authors read and approved the final manuscript. 


\begin{abstract}
Author details
${ }^{1}$ Department of Bioenergy, Agricultural Engineering College and Research Institute, Tamil Nadu Agricultural University, Coimbatore, Tamil Nadu 641003, India. ${ }^{2}$ Department of Chemistry, Boreskov Institute of Catalysis, Novosibirsk 630090, Russia. ${ }^{3}$ Biocatalysts Lab, Department of Agricultural Microbiology, Tamil Nadu Agricultural University, Coimbatore, Tamil Nadu 641003, India.
\end{abstract}

\section{Acknowledgements}

Thanks to Department of Biotechnology, New Delhi and Russian Ministry of Science and Technology, Russia.

\section{Competing interests}

The authors declare that they have no competing interests.

\section{Availability of data and materials}

All data generated or analyzed during this study are included in this published article.

\section{Consent for publication}

Not applicable.

\section{Ethics approval and consent to participate}

Not applicable.

\section{Funding}

We thank the Indo-Russian project on "Development of integrated (biotechnological and nanocatalytic) biorefinery for fuels and platform chemicals production from lignocellulosic biomass (crop/wood residues) No. DBT/NRM/ CBE/AGM/2014/R016)"for financial support.

\section{Publisher's Note}

Springer Nature remains neutral with regard to jurisdictional claims in published maps and institutional affiliations.

Received: 23 March 2018 Accepted: 11 July 2018

Published online: 24 July 2018

\section{References}

1. Sathitsuksanoh N, George A, Zhang Y, Percival H. New lignocellulose pretreatments using cellulose solvents: a review. J Chem Technol Biotechnol. 2013;88(2):169-80.

2. Silva GGD, Couturier M, Berrin J-G, Buléon A, Rouau X. Effects of grinding processes on enzymatic degradation of wheat straw. Bioresour Technol. 2012;103(1):192-200.

3. Zakaria MR, Norrrahim MNF, Hirata S, Hassan MA. Hydrothermal and wet disk milling pretreatment for high conversion of biosugars from oil palm mesocarp fiber. Bioresour Technol. 2015;181:263-9.

4. Zhou X, Ma J, Ji Z, Zhang X, Ramaswamy S, Xu F. Sun R-c: dilute acid pretreatment differentially affects the compositional and architectural features of Pinus bungeana Zucc. compression and opposite wood tracheid walls. Ind Crops Prod. 2014:62:196-203.

5. Ma L, Cui Y, Cai R, Liu X, Zhang C, Xiao D. Optimization and evaluation of alkaline potassium permanganate pretreatment of corncob. Bioresour Technol. 2015;180:1-6.

6. Qiu Z, Aita GM, Walker MS. Effect of ionic liquid pretreatment on the chemical composition, structure and enzymatic hydrolysis of energy cane bagasse. Bioresour Technol. 2012;117:251-6.

7. Amiri $\mathrm{H}$, Karimi K, Zilouei $\mathrm{H}$. Organosolv pretreatment of rice straw for efficient acetone, butanol, and ethanol production. Bioresour Technol. 2014:152:450-6.

8. Potumarthi R, Baadhe RR, Nayak P, Jetty A. Simultaneous pretreatment and saccharification of rice husk by Phanerochaete chrysosporium for improved production of reducing sugars. Bioresour Technol. 2013;128:113-7.

9. Oliva-Taravilla A, Moreno AD, Demuez M, Ibarra D, Tomás-Pejó E, González-Fernández C, Ballesteros M. Unraveling the effects of laccase treatment on enzymatic hydrolysis of steam-exploded wheat straw. Bioresour Technol. 2015:175:209-15.
10. Jiang W, Chang S, Li H, Oleskowicz-Popiel P, Xu J. Liquid hot water pretreatment on different parts of cotton stalk to facilitate ethanol production. Bioresour Technol. 2015:176:175-80.

11. Huang Y, Wei X, Zhou S, Liu M, Tu Y, Li A, Chen P, Wang Y, Zhang X, Tai H. Steam explosion distinctively enhances biomass enzymatic saccharification of cotton stalks by largely reducing cellulose polymerization degree in G. barbadense and G. hirsutum. Bioresour Technol. 2015;181:224-30.

12. Srinivasan N, Ju L-K. Statistical optimization of operating conditions for supercritical carbon dioxide-based pretreatment of guayule bagasse. Biomass Bioenergy. 2012;47:451-8.

13. Zhao C, Ding W, Chen F, Cheng C, Shao Q. Effects of compositional changes of AFEX-treated and H-AFEX-treated corn stover on enzymatic digestibility. Bioresour Technol. 2014;155:34-40.

14. Alvira P, Tomás-Pejó E, Ballesteros M, Negro M. Pretreatment technologies for an efficient bioethanol production process based on enzymatic hydrolysis: a review. Bioresour Technol. 2010;101(13):4851-61.

15. Baxi PB, Pandit AB. Using cavitation for delignification of wood. Bioresour Technol. 2012:110:697-700

16. Badve MP, Gogate PR, Pandit AB, Csoka L. Hydrodynamic cavitation as a novel approach for delignification of wheat straw for paper manufacturing. Ultrason Sonochem. 2014;21(1):162-8.

17. Nakashima K, Ebi Y, Shibasaki-Kitakawa N, Soyama H, Yonemoto T. Hydrodynamic cavitation reactor for efficient pretreatment of lignocellulosic biomass. Ind Eng Chem Res. 2016;55(7):1866-71.

18. Hilares RT, dos Santos JC, Ahmed MA, Jeon SH, da Silva SS, Han J-I. Hydrodynamic cavitation-assisted alkaline pretreatment as a new approach for sugarcane bagasse biorefineries. Bioresour Technol. 2016;214:609-14.

19. Kim I, Lee I, Jeon SH, Hwang T, Han J-I. Hydrodynamic cavitation as a novel pretreatment approach for bioethanol production from reed. Bioresour Technol. 2015;192:335-9.

20. Maran JP, Manikandan S, Nivetha CV, Dinesh R. Ultrasound assisted extraction of bioactive compounds from Nephelium lappaceum L. fruit peel using central composite face centered response surface design. Arab J Chem J. 2017;10:1145-57.

21. Mazaheri H, Lee KT, Bhatia S, Mohamed AR. Subcritical water liquefaction of oil palm fruit press fiber in the presence of sodium hydroxide: an optimisation study using response surface methodology. Bioresour Technol. 2010;101(23):9335-41.

22. Liu J-Z, Weng L-P, Zhang Q-L, Xu H, Ji L-N. Optimization of glucose oxidase production by Aspergillus niger in a benchtop bioreactor using response surface methodology. World J Microbiol Biotechnol. 2003;19(3):317-23.

23. Guo W-O Ren N-O, Wang X-J, Xiang W-S, Ding J, You Y, Liu B-F. Optimization of culture conditions for hydrogen production by Ethanoligenens harbinense B49 using response surface methodology. Bioresour Technol. 2009;100(3):1192-6.

24. Timung R, Mohan M, Chilukoti B, Sasmal S, Banerjee T, Goud VV. Optimization of dilute acid and hot water pretreatment of different lignocellulosic biomass: a comparative study. Biomass Bioenergy. 2015;81:9-18.

25. Maran JP, Sivakumar V, Sridhar R, Thirugnanasambandham K. Development of model for barrier and optical properties of tapioca starch based edible films. Carbohydr Polym. 2013;92(2):1335-47.

26. Mørch K. Energy considerations on the collapse of cavity clusters. In: Mechanics and physics of bubbles in liquids. New York: Springer; 1982. p. 313-21.

27. Wang Y-C, Brennen CE. The noise generated by the collapse of a cloud of cavitation bubbles. American Society of Mechanical Engineers; 1995. p. $17-29$.

28. Reisman G, Wang Y-C, Brennen CE. Observations of shock waves in cloud cavitation. J Fluid Mech. 1998;355:255-83.

29. Nagula KN, Pandit AB. Process intensification of delignification and enzymatic hydrolysis of delignified cellulosic biomass using various process intensification techniques including cavitation. Bioresour Technol. 2016;213:162-8.

30. Hilares RT, de Almeida GF, Ahmed MA, Antunes Felipe AF, da Silva SS, Han J-I, dos Santos JC. Hydrodynamic cavitation as an efficient pretreatment method for lignocellulosic biomass: a parametric study. Bioresour Technol. 2017;235:301-8. https://doi.org/10.1016/j.biortech.2017.03.125.

31. Marcilla A, García AN, Pastor M, León M, Sánchez A, Gómez D. Thermal decomposition of the different particles size fractions of almond shells and olive stones. Thermal behaviour changes due to the milling processes. Thermochim Acta. 2013:564:24-33. 
32. Song C, Hu H, Zhu S, Wang G, Chen G. Nonisothermal catalytic liquefaction of corn stalk in subcritical and supercritical water. Energy Fuels. 2004;18(1):90-6.

33. Caballero J, Marcilla A, Conesa J. Thermogravimetric analysis of olive stones with sulphuric acid treatment. J Anal Appl Pyrolysis. 1997:44(1):75-88.

34. Chen WH, Tu YJ, Sheen HK. Impact of dilute acid pretreatment on the structure of bagasse for bioethanol production. Int J Energy Res 2010:34(3):265-74.

35. Grimaldi MP, Marques MP, Laluce C, Cilli EM, Sponchiado SRP. Evaluation of lime and hydrothermal pretreatments for efficient enzymatic hydrolysis of raw sugarcane bagasse. Biotechnol Biofuels. 2015;8(1):205.

36. Kassim M, Potumarthi R, Tanksale A, Srivatsa S, Bhattacharya S. Enzymatic saccharification of dilute alkaline pre-treated microalgal (Tetraselmis suecica) biomass for biobutanol production. Int J Food Agric Vet. 2014;8:967-72.

37. Krause DO, Denman SE, Mackie RI, Morrison M, Rae AL, Attwood GT, McSweeney CS. Opportunities to improve fiber degradation in the rumen: microbiology, ecology, and genomics. FEMS Microbiol Rev. 2003;27(5):663-93.

38. Malherbe S, Cloete TE. Lignocellulose biodegradation: fundamentals and applications. Rev Environ Sci Bio. 2002;1 (2):105-14.

39. Zhang J, Hou W, Bao J: Reactors for high solid loading pretreatment of lignocellulosic biomass. In: Bioreactor engineering research and industrial applications II. Berlin: Springer; 2015. p. 75-90.

40. Winkler M. Problems in fermenter design and operation. Chemical Engineering Problems in Biotechnology; 1990. p. 215-350.

41. Kiruthika T, Ramesh D, Sivakumar U. Rheology of different corncob biomass slurries for hydrodynamic cavitation based biomass pretreatment process. Madras Agric J. 2017;104:279-81. https://doi.org/10.29321/ MAJ.2017.000060.

42. Gonçalves I, Silva C, Cavaco-Paulo A. Ultrasound enhanced laccase applications. Green Chem. 2015;17(3):1362-74.

43. Christopher LP, Yao B, Ji Y. Lignin biodegradation with laccase-mediator systems. Front Energy Res. 2014;2:12.
44. Kunamneni A, Plou FJ, Ballesteros A, Alcalde M. Laccases and their applications: a patent review. Recent Pat Biotechnol. 2008;2(1):10-24.

45. Sluiter A, Hames B, Ruiz R, Scarlata C, Sluiter J, Templeton D, Crocker D. Determination of structural carbohydrates and lignin in biomass. Lab Anal Proc. 2008;1617:1-16.

46. Morshedi A, Akbarian M. Application of response surface methodology: design of experiments and optimization: a mini review. J Fund Appl Life Sci. 2014;54:2434-9.

47. Box GE, Behnken DW. Some new three level designs for the study of quantitative variables. Technometrics. 1960;2(4):455-75.

48. Segal L, Creely J, Martin A Jr, Conrad C. An empirical method for estimating the degree of crystallinity of native cellulose using the $X$-ray diffractometer. Text Res J. 1959;29(10):786-94.

49. Rodrigues Filho G, de Assunção RM, Vieira JG, Meireles CS, Cerqueira DA, Barud SH, Ribeiro SJ, Messaddeq Y. Characterization of methylcellulose produced from sugar cane bagasse cellulose: crystallinity and thermal properties. Polym Degrad Stab. 2007;92(2):205-10.

50. Sun J, Peng R-H, Xiong A-S, Tian Y, Zhao W, Xu H, Liu D-T, Chen J-M, Yao Q-H. Secretory expression and characterization of a soluble laccase from the Ganoderma lucidum strain 7071-9 in Pichia pastoris. Mol Biol Rep. 2012;39(4):3807-14

51. Barki M, Ganesha T, Math M. CFD analysis and comparison of fluid flow through a single hole and multi hole orifice plate. Int J Res Adv Technol. 2014;2(8):6-15.

52. Sivakumar $M$, Pandit AB. Wastewater treatment: a novel energy efficient hydrodynamic cavitational technique. Ultrason Sonochem. 2002:9(3):123-31.

53. Bashir TA, Soni AG, Mahulkar AV, Pandit AB. The CFD driven optimisation of a modified venturi for cavitational activity. Can J Chem Eng. 2011;89(6):1366-75
Ready to submit your research? Choose BMC and benefit from:

- fast, convenient online submission

- thorough peer review by experienced researchers in your field

- rapid publication on acceptance

- support for research data, including large and complex data types

- gold Open Access which fosters wider collaboration and increased citations

- maximum visibility for your research: over $100 \mathrm{M}$ website views per year

At BMC, research is always in progress.

Learn more biomedcentral.com/submissions 